\title{
Game Based Entrepreneurship Learning for Vocational High School Students in Facing 4.0 Industry
}

\author{
Indra Febrianto $^{\text {a,* }}$, Heny Kusdiyanti ${ }^{\text {b }}$, Chau Kien Tsong ${ }^{c}$ \\ ${ }^{a}$ Master of Economic Education, Faculty of Economics and Business, \\ Universitas Negeri Malang \\ ${ }^{b}$ Management Major, Faculty of Economics and Business, \\ Universitas Negeri Malang \\ ${ }^{c}$ Center for Instructional Technology and Multimedia, \\ Universiti Sains Malaysia
}

*Corresponding author's e-mail: indrafebrianto31@gmail.com

\begin{abstract}
This study aims to analyze game-based entrepreneurship learning conducted on vocational high school students in facing Industry 4.0. This research used a literature review method with descriptive analysis through the provision of clear, factual, logical, and systematic discussion. This research used content analysis. The results of this study suggest that technology implementation is unquestionably required in the entrepreneurship learning process for the attainment of students' competences in the 4.0 Industry. Those competencies include social skills, one of the cross-functional skills, in the 4.0 Industry era that can be implemented through social entrepreneurship. In addition, game-based learning is effective to be applied to offer new different learning experiences. Those experiences are 1) learning by doing, 2) reflective learning, 3) situated learning, and 4) learning from crises. This learning is an alternative solution to prepare vocational high school students to encounter the 4.0 Industry.
\end{abstract}

Keywords: game-based learning, entrepreneurship learning, 4.0 Industry, vocational high school students

\section{Introduction}

Vocational high school graduates are placed at the highest rank of open unemployment in Indonesia. The official data from Central Statistics Body record the open unemployment level of vocational high school graduates, up to August 2019, reaches 7.05 million [33]. This substantial number dominates $10 \%$ of the total open unemployment in Indonesia. 


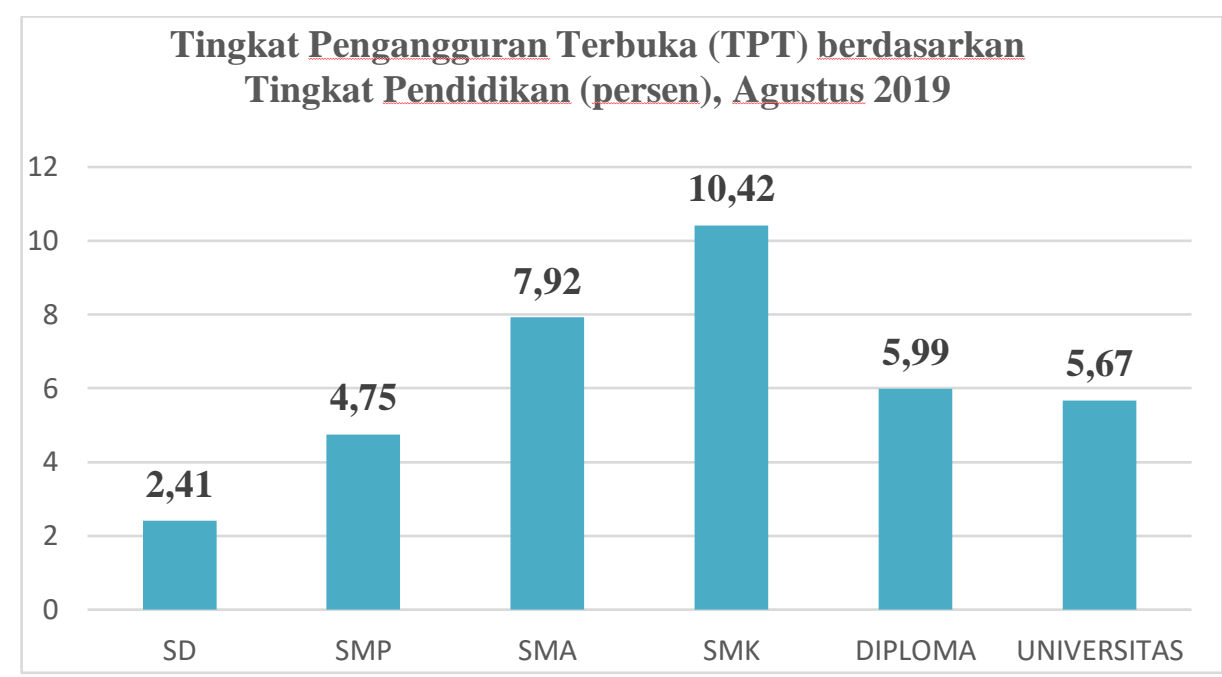

Figure 1. Open Unemployment Level of Vocational High School Graduates source: Central Statistics Body, 2019

Ironically, the purpose of vocational high schools is to massively contribute to the decrease of Indonesia's unemployment rate through their innovation and creativity. The primary cause of the high open unemployment rate is the incompatibility of vocational high school students' skills and the industry demand [14]. The situation is worsened by the unbalance number of employment and vocational high school graduates every year [3].

Numerous efforts have been carried out by the Directorate of Vocational High School Development of Education and Culture Ministry to resolve this issue. One of the recent efforts is the establishment of an entrepreneurship program combined with the 'Learn, Continue Study, and Entrepreneurship' program. This combination focuses on business and production-based learning for vocational high school students. Besides, the government has also modified the entrepreneurship course that mostly concentrates only on the theoretical aspect with no innovative and creative outputs. The course adjustment follows Decree of Director General of Elementary and Secondary Education No. 130/D/KEP/KR/2017 on the 2017 vocational high school curriculum structure that modifies entrepreneurship courses into the product, creative and entrepreneurship course. This course becomes one of the fields of interest in vocational high schools that accelerates students' creativity and innovation to be an entrepreneur.

Further, this course will be the pioneer of young businessmen contributing to economic growth. As for the fact, small and medium enterprises carry a substantial contribution of $60.34 \%$ toward Indonesia's gross domestic product (GDP) [35]. Head of Indonesia small and medium enterprises association predicts that this contribution will grow $5 \%$ to $6.5 \%$ or around $\mathrm{Rp} 2.394,5$ trillion in 2020. Thus, entrepreneurship learning becomes an essential part of education institutions. 
Various studies discover a relationship between global problem solving and entrepreneurship [26], [27], [28], [39]. Findings on those studies identify entrepreneurship as a solution to global problems.

On the other hand, product, creative, and entrepreneurship courses have not prepared students with excellent entrepreneur behavior, character, and attitude with the ability to create employment [20]. Consequently, it contributes to the high number of open unemployment from vocational high school graduates. Further, the course only gains minimum attention from students and teachers as proven from the monotonous material delivery that fails to attract students' attention to learn the material further [9]. Besides, teachers also face difficulties in delivering material contextually [41].

As the 4.0 Industry has demanded technology to be the basis of everyday human life, teachers are also demanded to adopt technology as the learning media [22]. It is also supported by the official data that reveal Indonesia as a country with the highest usage of handphones, $95 \%$ or 142 million from a total of 150 million Internet users in Indonesia. According to a survey conducted by Forbes in 2019, $76 \%$ of Indonesia internet users purchase their phones. This places Indonesia as the highest mobile e-commerce among countries across the world.

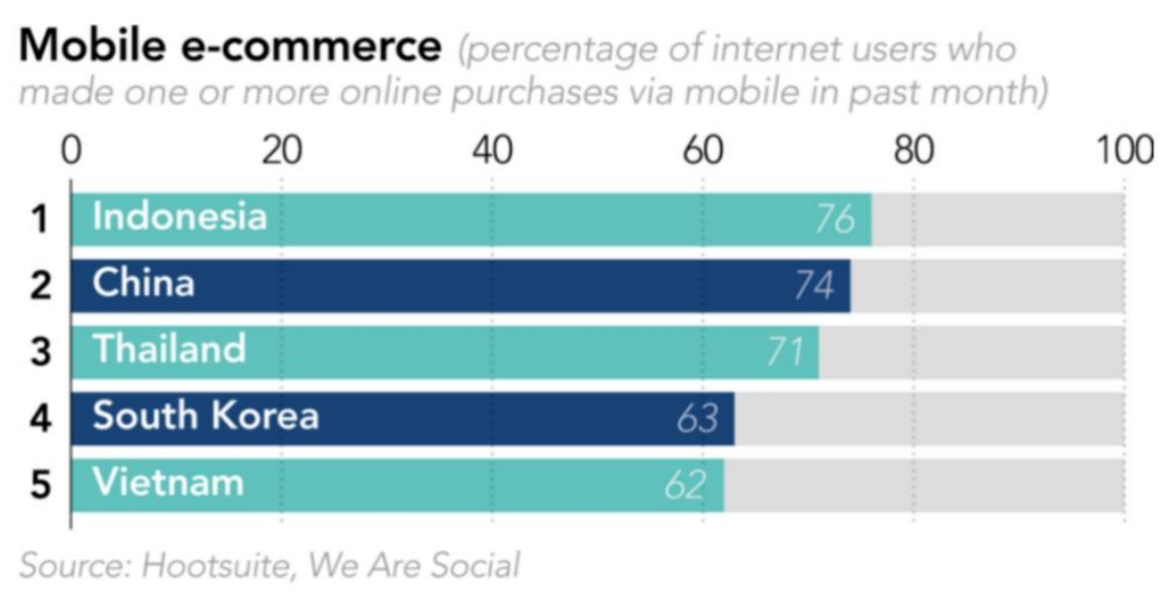

Figure 2. Mobile E-Commerce in Indonesia source: Forbes, 2019

Therefore, the use of games as learning media brings an immense potential in learning. In addition to the high demand for games, game-based learning motivates students to learn since the teaching is contextually designed to be more attractive [11]. Students obtain real experiences by using gamebased learning. Later, this will accelerate students' interest in the Product, Creative, and Entrepreneurship course [42]. The success of this course generates competent young entrepreneurs that decrease the number of open unemployment from vocational high schools in Indonesia. 


\section{Method}

This research is a literature review research. Literature related to learning in the 4.0 Industry era was selected. The data were secondary data from reliable sources, such as the Central Statistics Body and Forbes. By using this data, a descriptive analysis was conducted by providing a clear, factual, logical, and systematic explanation. Content analysis was selected as the analysis technique to reveal results in the context of economy learning from an entrepreneurship perspective in the 4.0 Industry era.

\section{Results and Discussion}

\section{Results}

In the 4.0 Industry, learning processes and objectives have shifted. There are numerous challenges to be considered by many stakeholders, especially teachers, as the education practitioner. The changes are closely related to the massive usage of technology in daily human life [30]. The usage of technology has become the primary key for the task efficiency and effectivity. Consequently, people have to improve their skills to work through digital technology [13]. This demand also reaches vocational high school students in preparing themselves for the work field. Their competencies are their primary capital to create innovation in the work field. These students are equipped to be entrepreneurs who open employment, not to be an employee in a company. This becomes an alternative solution for the discrepancy between the demand for jobs and numbers of vocational high school graduates [3], [14]. Once it is successfully executed, government expectations for those graduates will be realized.

The objectives will be easily obtained through learnings that fit the current era. In relation to the 4.0 Industry, adjustments of education are required with consideration of the humanities aspect [1]. In vocational high schools, a learning objective to improve students' skills collaboration is urgently needed by the graduates. This skills collaboration will also equip students to encounter 4.0 Industry. After students graduated, they have to adjust their skills with the demanded skills that shifted every year. The shifts of the required skills are illustrated in Figure 3. 


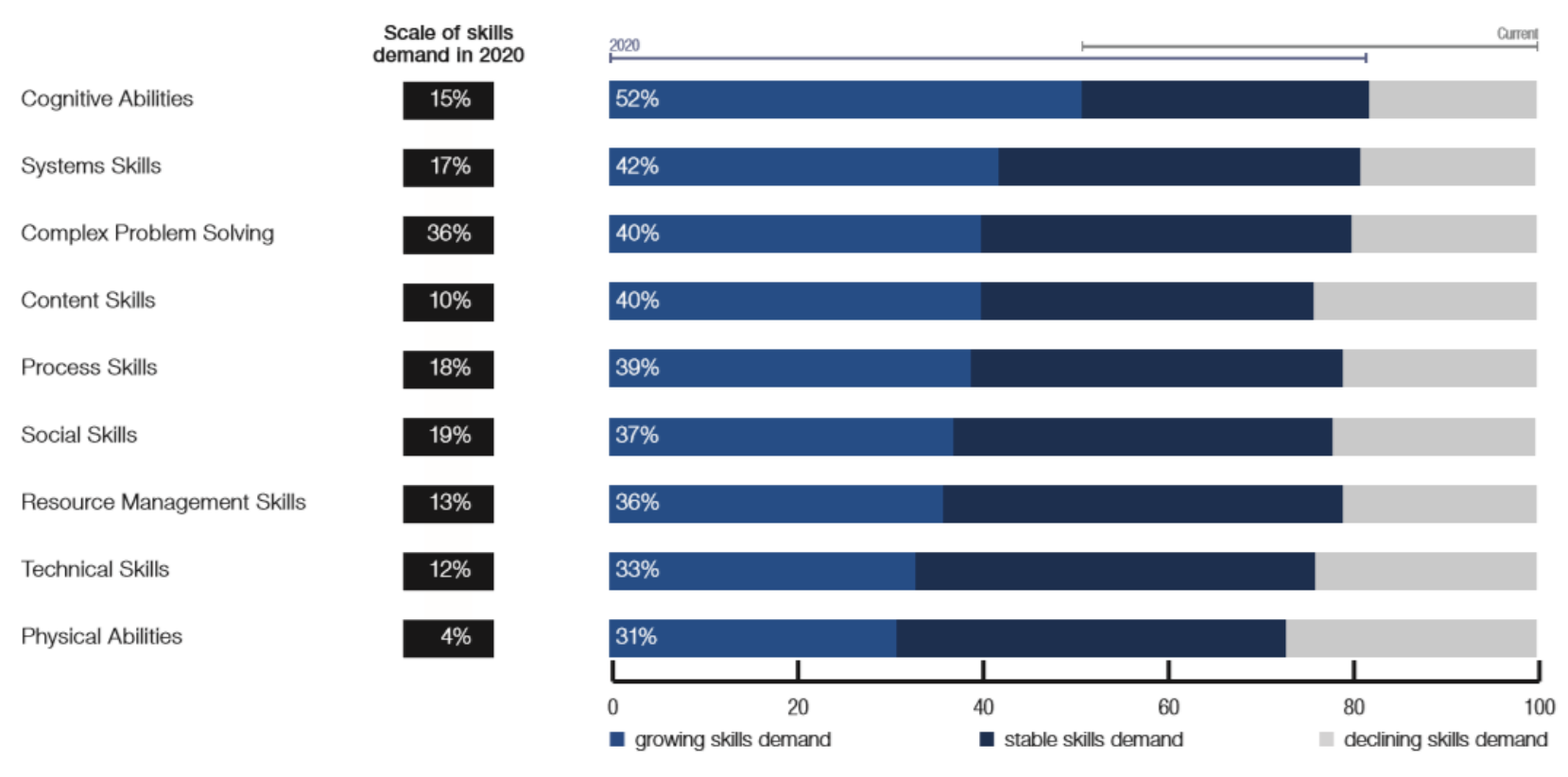

Figure 3. Shifts of Required Skills in 4.0 Industry

Source : (Klaus Schwab \& Samans, 2016)

According to Figure 3, complex problem solving and social skills are the most demanded skills in 2020. The complex problem solving and social skill gain $36 \%$ and $19 \%$ rate, respectively, on the most demanded skill scale. This can be a reference for vocational high school learning to aim for this expertise. Along with the upsurge on, students need to improve those skills, personalized learning experience that allows students to choose their ways of learning, have to be provided. Students potentially adjust their learning with the needed tools [18]. They can learn with various devices, programs, and techniques.

The shift of learning paradigm and action patterns are required. The logical consequences of the continuously developed technology innovation require conceptual adjustment on classroom management and learning method to adjust the learning style to students' interest. Following the demanded personalized learning, the proper learning model becomes the key to learning success. Currently, game-based learning is the preferred learning strategy for every class level and has become more prominent since it effectively provides contextual learning experience through simulation within a game [11]. This learning is also an alternative to improve students' competence following 4.0 Industry demands. Some matters to be considered by teachers and schools to decide the learning implementation in 4.0 Industry are presented in Figure 4 [18]. 


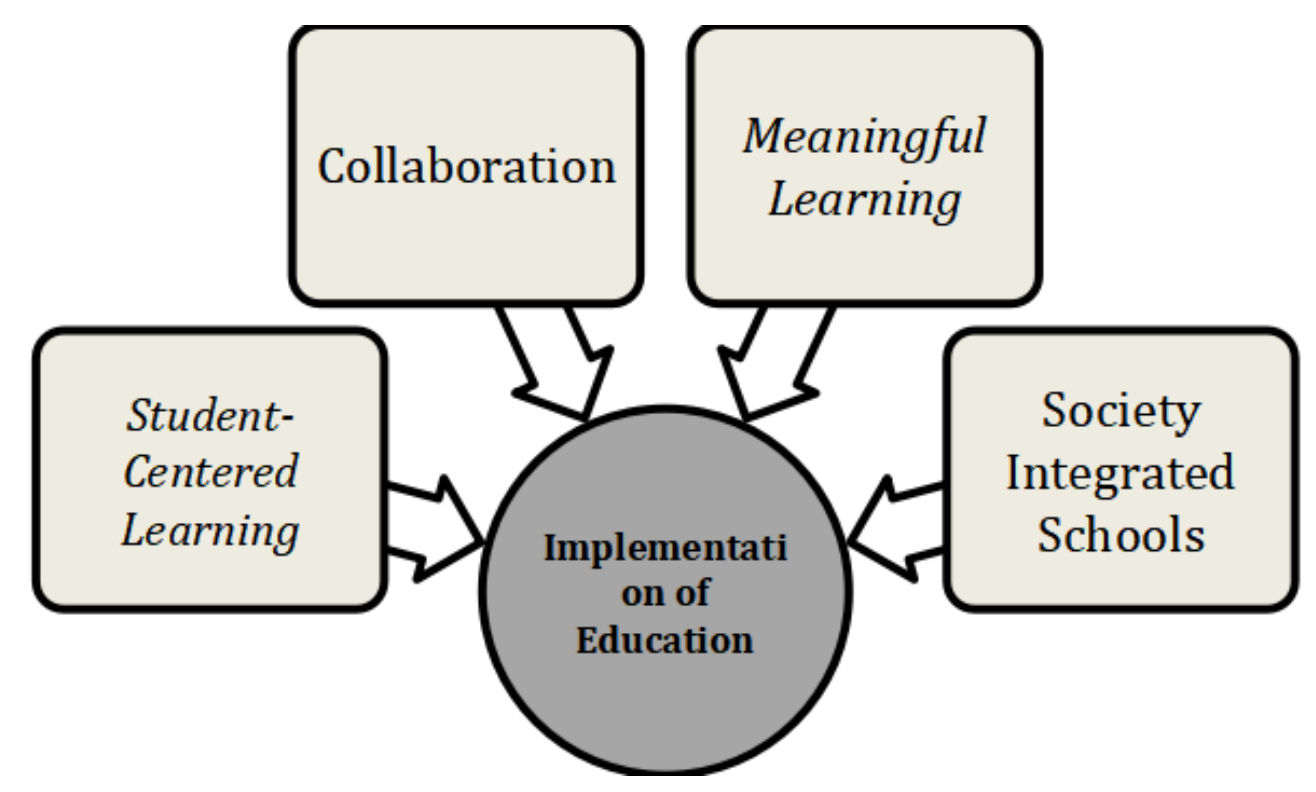

Figure 4. Essential Points of 4.0 Industry Learning source: researchers' document

There are some critical points that need to be considered in 4.0 Industry learning. The first point is student-centered learning, where teachers no longer become the only primary learning source in the classroom. Students have to gain the latest information on the current issue (learning how to learn) to be able to compete with and contribute to global society in the future. Further, they also need to associate their new information with their initial knowledge to solve the issue.

In the class model, the teacher only acts as a facilitator, while students independently gather information with teacher guidance. At the same time, teachers have to accommodate students' learning styles to enhance students learning motivation and responsibility since students actively involved in the various learning activities. Learning is about discovering, not remembering terms. The second point is collaboration, where students are encouraged to collaborate in finding information, collecting information, and establish the meanings. The ability to identify the different strengths and talents carried by each member into the project (project-based learning) and change the roles highly relies on the establishment of collaborative learning by the school, teachers, and students. It is essential for students to collaborate with others. Currently, all people in this world collaborate. Thus, students are expected to work with people from different cultures with different values; therefore, they need to be able to work with people they meet every day, first. Additionally, schools have to collaborate with other educational institutions in the whole world to share information and learn about the current advanced practices and methods. They have to be willing to adjust their learning method. 
The third point is meaningful learning, where the learning is students centered, but the teacher still manages the class. While the students are encouraged to learn in with their learning style, the teacher still offers guidance for students' skills attainment. The teacher can initiate critical points to aid students to comprehend ways to implement the obtained skills so that the students are motivated to learn beneficial matters. Teachers have to teach and train the students' skills required in every situation. Learning becomes meaningless and has no purpose if it brings no effect on students' life outside the school.

The fourth point is society-integrated school. With the help of technology and the internet, students can perform various things. School community no longer consists of only the school area, but it extends to the whole world. Education is supposed to help students to take part in the global community and find ways to brings influence to a broader environment. However, it does not erase their responsibility to helps people in their surroundings. They have also to learn to promote and protect the environment that is far away from them. Besides, schools need to teach students to be a responsible society. Through the school community, students are stimulated to take part in numerous projects and activities and help the people of the surroundings through various social events.

In the vocational high school learning process, teachers also have to consider those essential matters. That will be the primary matrix in the preparation of the lesson plan that results in the expected results in 4.0 Industry learning. Other than that, the technology advancement also brings students' negative behavior and character transformation. Students may also face several harmful threats during technology-based learning, primarily game-based learning. As a result, the teacher holds a significant role in shaping students' character. Teachers are expected to deliver knowledge, as well as develop students' attitudes and spiritual to create a balance between intellectual and spiritual competence.

\section{Discussion}

\section{a. Entrepreneurship Learning in 4.0 Industry Era}

Following the immense contribution of Indonesia's small and medium enterprises, entrepreneurship learning should be effectively and efficiently conducted. It covers not only ways to be a seller or marketing agent, but also ways to be a creator and innovator [24]. This incorrect paradigm is prevalent in society. Many people misunderstand the definition of entrepreneurship, resulting in the improper implementation of entrepreneurship learning. School entrepreneurship learning mostly focusses on the ways to sell or promote products with no strategy in deciding the product potential for the market. 
This has become a concern for entrepreneurship learning practitioners, primarily in the education institution environment. Vocational high school is one of the educational institutions that effectively apply entrepreneurship learning. The creativity and innovation of vocational high school students can be combined with the entrepreneurship attitude to create innovative products and escalate society's income [37]. The success of entrepreneurship learning is expected by various circles, particularly the entrepreneurship learning practitioners.

The implementation of entrepreneurship learning is flexible. Currently, industry revolution occurs in Indonesia as technology has become the basis of daily human life [19]. In line with this development, entrepreneurship learning has to be conducted in a more effective and efficient means. The use of proper technology for students' character is critical, as there are various technologies that can be adopted by teachers [21]. This enables the teacher to get the suitable technology to support entrepreneurship learning. Further, technology has a close relation with learning, as it is the appropriate media for learning [2]. Thus, it provides sufficient potential to attain the success of entrepreneurship learning, primarily in vocational high schools.

The implementation of technology in entrepreneur learning is related to the learning objectives following the current 4.0 industry. While teachers who have to improve their teaching skills, students also have to shift their skills into communication, critical thinking and problem solving, collaboration, as well as creativity and imagination (4C). These competencies are required for students in the 21 st century who also encounter 4.0 Industry era [10], [40]. The competencies are highly relevant in the entrepreneur world, where the teacher becomes a facilitator during this technology-based learning [23]. It is in accordance with the values of entrepreneurship, such as being creative and innovative [34]. The attainment of these 4C competencies in vocational high school entrepreneurship learning starts the birth of young entrepreneurs who produced various innovative products.

Implementation of entrepreneurship learning in the 4.0 Industry era does not only focus on the attainment of students' competencies but also refers to the role of those competencies in society. Other than those $4 \mathrm{c}$ competencies, students have to also possess social skills that primarily demanded by the 4.0 Industry [29]. There are numerous competencies to be obtained in social skills, such as coordinating with others and service orientation. 


\section{Abilities}

Cognitive Abilities
- Cogritive Flexibility
- Creativity
- Logical Reasoning
- Problem Sensitivity
- Mathematical Reasoning
- Visualization

\section{Physical Abilities}

, Physical Strength

Manual Dextority and

Precision

\section{Basic Skills}

Content Skills

- Active Learning

- Oral Expression

Reading

Comprehension

Written Expression

, ICT Literacy

Process Skills

* Active Listening

, Critical Thinking

Monitoring Self and

Others

Source: World Economic Forum, based on O'NET Content Model. Note: See Appendlx A for further detalls.

Figure 5. Competencies in 4.0 Industry

source: World Economic Forum, 2016

Based on Figure 5, social skills belong to the cross-functional expertise that should be possessed in the 4.0 Industry era. In relation to entrepreneurship, there is a branch that leads to social skills; that is, social entrepreneurs. Social entrepreneurship refers to entrepreneurship that runs a business focusses on both profits, as well as the social effect [4]. Also, this type of entrepreneurship carries a significant contribution to social welfare, especially those in a suburban area [25], [32]. The model of social entrepreneurship, as illustrated in Figure 6, can also be implemented in entrepreneurship learning in the 4.0 Industry era. 


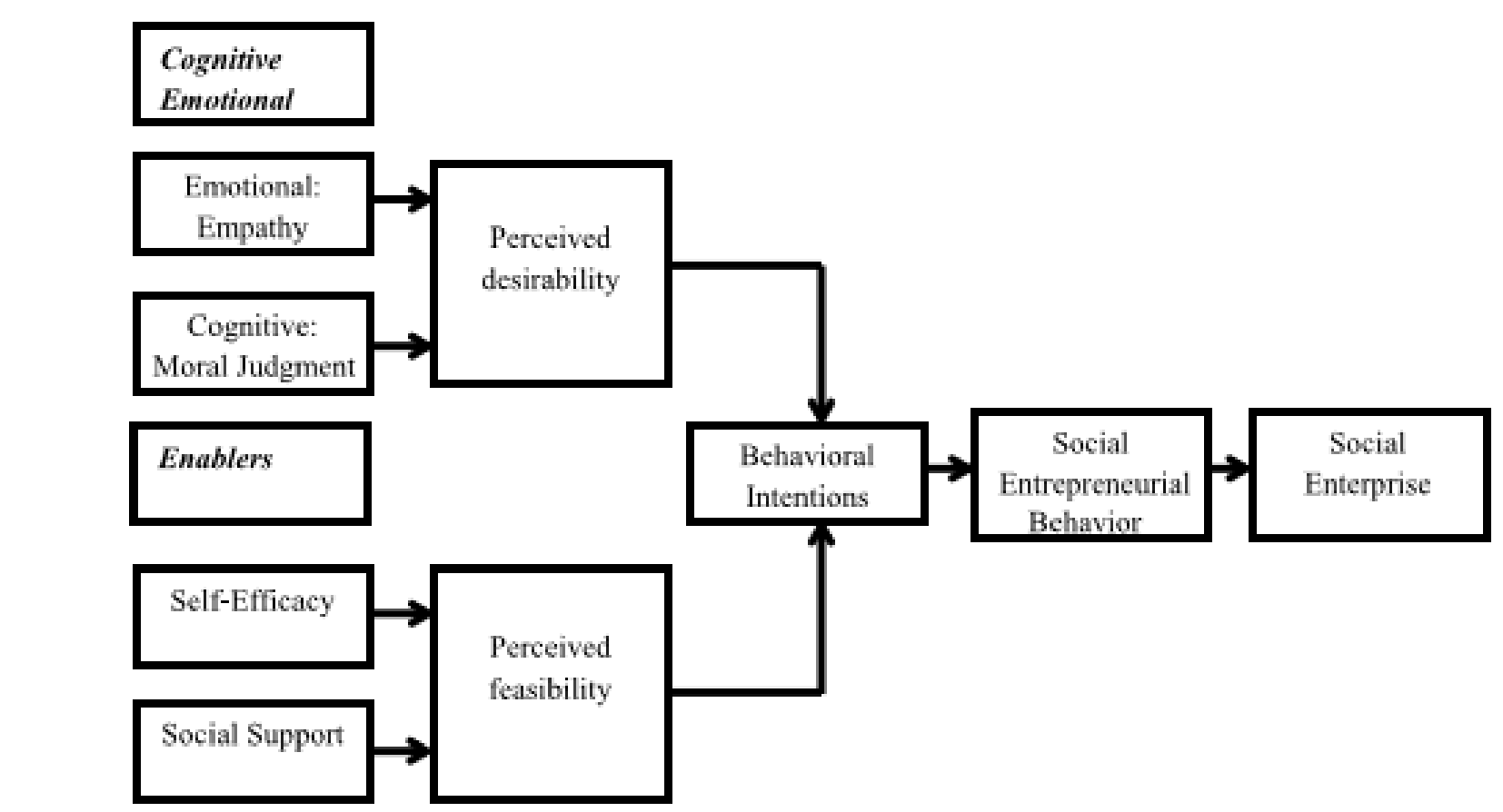

Source: Mair and Noboa(2006)

Figure 6. Model of Social Entrepreneurship

Source: (Pathak et al., 2018)

Therefore, the attainment of social skills is compulsory for all of the students. Other than the benefits for students, this learning also carries advantages for the surrounding area. The inclusion of social entrepreneurship in the learning shapes young entrepreneur that not only focusses on profit but also on the advantages of the business.

\section{b. Game-Based Entrepreneurship Learning}

There are various models that can be adopted in entrepreneurship learning. One of the proper learning models is game-based learning [7]. The implementation of this learning model brings contextual experience for students to conduct entrepreneurship activities. Students directly complete the activities that sharpened their critical thinking during entrepreneurship learning. The game-based learning model is one of the efforts administered to prepare qualified human resources to face the 4.0 Industry [11], [12], [36]. The realization of these competencies strengthens the implementation of entrepreneurship learning.

The implementation of game-based learning in the entrepreneurship courses does not belong to new practices in the Educational world. There have been numerous studies that investigated the implementation of this learning model [6], [8]. Those studies have confirmed the successful implementation of this game-based learning model in entrepreneurship learning. Besides improving 
students' critical thinking, this learning model also offers a various learning experience for students, such as learning by doing, reflective learning, situated learning, and learning from crises [8].

\section{Learning by Doing}

Learning by doing is one of the essential learning experiences obtained by students from entrepreneurship learning. From designed learning, the students are imposed to feel the given assumption and new knowledge. Simulation becomes one of the proper means to provide this learning experience to students. The applied game-based learning aids students to simulate their desirable business. Besides, this learning also offers emotional, financial, and social exposure experience to improve students' comprehension of entrepreneurship learning [31]. This learning by doing experience is utterly experienced by students using game-based learning, which accommodates the related entrepreneurship. This is also in accordance with personalized learning, the learning that should be held in the 4.0 Industry era, that is appropriate with students' individual demands [15]. Additionally, this learning also promotes students' creativity that is essential in entrepreneurship.

\section{Reflective Learning}

Reflective learning is critical to measure students' attained results in completing a game. In gamebased learning, the designed game should inspire students to do a reflection on the game they have played [8]. This learning enables students to get experience in creating decisions during entrepreneurship-related games. From the decisions taken by students, an outcome is generated. Later, this outcome becomes the material for students' reflection. During the reflection, students identify the incorrect strategies that need to be reinforced to be a winner for the game. Additionally, students are also encouraged to think critically in reflecting on their outcome. Besides, this reflection also eases teachers in deciding the conclusion for each of the learning [16]. Students' experiences in doing a reflection also support the success of entrepreneurship learning.

\section{Situated Learning}

Learning experiences based on situations assist students in gaining better comprehension of the entrepreneurship practices. The planned game simulation has the various situation in each condition. Students are provided with numerous competitors, as well as stakeholders related to their businesses. During this situation, students learn the ways to face each competitor or stakeholder to maximize their business. The situated learning is critical for this era due to the more complex competencies demanded to be possessed by students [38]. 


\section{Learning from Crises}

Other than learning experience based on the situation, the implementation of game-based learning also offers the learning from crises for students. In the planned game scenarios, some crises are designed to be given to students during the business simulation process in their business ecosystem. Students have to analyze different possibilities of failures and successes while responding to the crises. Later, these activities accelerate students' understanding on the whole entrepreneurship material, from planning to evaluation [5]. This learning process also sharpens the emotional intelligence of each student.

The learning experiences mentioned above are the supports that significantly contribute to the success of game-based learning in an entrepreneurship course. Additionally, another critical point to be considered in entrepreneurship learning is the game scenarios used. Teachers can easily arrange the game scenario implemented in learning. However, those scenarios should be in line with the final objectives. If there are challenges during the organization of game scenarios, the teacher can use the existing entrepreneurship game simulation. One of the example of an entrepreneurship game simulator is "Craftivity" that designed explicitly for entrepreneurship learning in vocational high schools.

\section{Conclusions}

In accordance with the immense contribution of small and medium enterprises in Indonesia, entrepreneurship learning should be effectively and efficiently conducted in vocational high school as an effective educational institution that implements entrepreneurship learning. Vocational high school students' creativity and innovation can collaborate with the entrepreneurship attitude that will produce an innovative product and accelerate the surrounding society's income. Thus, teachers are encouraged to find a breakthrough for entrepreneurship learning. Additionally, in line with the current 4.0 Industry, the use of technology in the learning process becomes obligatory. This use of technology follows the demand of students' competences in the 21 st century, including communication, critical thinking and problem solving, collaboration, as well as creativity, and imagination. The implementation of entrepreneurship learning during the 4.0 Industry era has to also support the attainment of students' social skills, as the cross-functional skills that are demanded in this era, through the social entrepreneurship model.

A game-based learning model was selected since it is relatively useful for entrepreneurship learning in vocational high schools. This learning model offers a direct simulation of the business 
that carries contextual experiences for students. This experience improves students' understanding of the entrepreneurship material. Also, entrepreneurship learning through game simulation brings new learning experiences for students. Those experiences include learning by doing, reflective learning, situated learning, and learning from crises. The selection of the game scenarios is adjusted to the teacher's condition. Teachers can also use the existing game, such as "Craftivity." Gamebased entrepreneurship learning is one of the alternative solutions to prepare vocational high school students to face the current 4.0 Industry.

\section{References}

[1] Ahmad, I. (2018). Proses Pembelajaran Digital dalam Era Revolusi Industri 4 . 0 Era Disrupsi Teknologi. Kementerian Riset, Teknologi, Dan Pendidikan Tinggi, 1-13.

[2] Balakrishnan, V., \& Gan, C. L. (2016). Students' learning styles and their effects on the use of social media technology for learning. Telematics and Informatics, 33(3), 808-821. https://doi.org/10.1016/j.tele.2015.12.004

[3] Basri, I. Y., Faiza, D., Nasir, M., \& Nasrun, N. (2019). Implementasi Pembelajaran Berbasis Produk Dalam Rangka Menyiapkan Lulusan SMK Menjadi Wirausahawan Muda. INVOTEK: Jurnal Inovasi Vokasional Dan Teknologi, 19(1), 43-52. https://doi.org/10.24036/invotek.v19i1.433

[4] Boulven, M. A., Abdullah, S., Bahari, A., Ramli, A. J., Hussin, N. S., Jamaluddin, J., \& Ahmad, Z. (2018). Model of Islamic Social Entrepreneurship: A Study on Successful Muslim Social Entrepreneur in Malaysia. MATEC Web of Conferences, 150, 10-13. https://doi.org/10.1051/matecconf/201815005093

[5] Doern, R. (2016). Entrepreneurship and crisis management: The experiences of small businesses during the London 2011 riots. International Small Business Journal: Researching Entrepreneurship, 34(3), 276-302. https://doi.org/10.1177/0266242614553863

[6] El-awad, Z. E., Gabrielsson, J., \& Politis, D. (2017). Entrepreneurial learning and innovation: The critical role of team-level learning for the evolution of innovation capabilities in technologybased ventures International Journal of Entrepreneurial Behavior \& Research Article information : (February). https://doi.org/10.1108/IJEBR-06-2016-0177

[7] Fellnhofer, K. (2018). Game-based Entrepreneurship Education: Impact on Attitudes , Behaviours and Intentions. 3(July). https://doi.org/10.1504/WREMSD.2018.089066 
[8] Fox, J., Pittaway, L., \& Uzuegbunam, I. (2018). Simulations in Entrepreneurship Education : Serious Games and Learning Through Play. https://doi.org/10.1177/2515127417737285

[9] Genefri, Kusumaningrum, I., Dewy, M. S., \& Anori, S. (2017). Learning Outcomes in Vocational Study: A Development of Product Based Learning Model. Medwell Journal, 12(5), 831-838. https://doi.org/10.3923/sscience.2017.831.838

[10] Guzmán-Simón, F., García-Jiménez, E., \& López-Cobo, I. (2017). Undergraduate students’ perspectives on digital competence and academic literacy in a Spanish University. Computers in Human Behavior, 74, 196-204. https://doi.org/10.1016/j.chb.2017.04.040

[11] Hamari, J., Shernoff, D. J., Rowe, E., Coller, B., Asbell-Clarke, J., \& Edwards, T. (2016). Challenging games help students learn: An empirical study on engagement, flow and immersion in game-based learning. Computers in Human Behavior, 54, 170-179. https://doi.org/10.1016/j.chb.2015.07.045

[12] Huizenga, J. C., ten Dam, G. T. M., Voogt, J. M., \& Admiraal, W. F. (2017). Teacher perceptions of the value of game-based learning in secondary education. Computers and Education, 110, 105-115. https://doi.org/10.1016/j.compedu.2017.03.008

[13] ILO. (2017). Indonesia Jobs Outlook 2017: Harnessing technology for growth and job creation. In LinkedIn. Retrieved from https://www.ilo.org/wcmsp5/groups/public/---asia/---ro-bangkok/--ilo-jakarta/documents/publication/wcms_613628.pdf

[14] Jatmoko, D. (2013). Relevansi kurikulum SMK kompetensi keahlian teknik kendaraan ringan terhadap kebutuhan dunia industri di Kabupaten Sleman. Jurnal Pendidikan Vokasi, 3(1), 1-13. https://doi.org/10.21831/jpv.v3i1.1572

[15] Karmokar, S. (2016). Creative Entrepreneurship: Integrating Entrepreneurial Method and Experience of Learning by Doing. Journal of Creativity and Business Innovation, 2, 80-88.

[16] Kheng, Y. K. (2017). The Inculcation of Critical Reflection through Reflective Learning Log: An Action Research in Entrepreneurship Module. International Education Studies, 10(12), 153. https://doi.org/10.5539/ies.v10n12p153

[17] Kurowska-Pysz, J. (2016). Opportunities for cross-border entrepreneurship development in a cluster model exemplified by the Polish-Czech border region. Sustainability (Switzerland), 8(3). https://doi.org/10.3390/su8030230

[18] Lase, D. (2019). Pendidikan di Era Revolusi Industri 4.0. SUNDERMANN Jurnal Ilmiah Teologi Pendidikan Sains Humaniora Dan Kebudayaan, 1(1), 28-43. https://doi.org/10.36588/sundermann.v1i1.18

[19] Maryadi, W. W. (2010). Strategi Perguruan Tinggi dalam Upaya Meningkatkan Kualitas Sumberdaya Manusia. Majalah Ilmiah Lontar, 24(2), 27-36. 
[20] Maya, P., \& Suparman. (2019). TINGKAT PEMAHAMAN GURU TERHADAP KARAKTERISTIK DAN PENERAPAN MODEL PROJECT BASED LEARNING ( PjBL ) DALAM PEMBELAJARAN PRODUK KREATIF DAN KEWIRAUSAHAAN ( PKK ) Badan Pusat Statistik ( BPS ) tahun 2017 dapat dijelaskan persentase pengangguran siswa SMK sebes. JPTS, I(1), 73-80.

[21] Mina, L. W. (2019). Analyzing and Theorizing Writing Teachers' Approaches to Using New Media Technologies. Computers and Composition, 52, 1-16. https://doi.org/10.1016/j.compcom.2019.01.002

[22] Mkwanazi, S., \& Mbohwa, C. (2018). Implications of the 4 th Industrial Revolution on Entrepreneurship Education.

[23] Muhonen, H., von Suchodoletz, A., Doering, E., \& Kärtner, J. (2019). Facilitators, teachers, observers, and play partners: Exploring how mothers describe their role in play activities across three communities. Learning, Culture and Social Interaction, 21(March), 223-233. https://doi.org/10.1016/j.lcsi.2019.04.002

[24] Nurseto, T. (2010). PENDIDIKAN BERBASIS ENTREPRENEUR. Jurnal Pendidikan Akuntansi Indonesia, 1(4), 53. Retrieved from file://C:/Users/WINDOWS 8.1/Downloads/9542987-1-PB.pdf

[25] Pathak, R. R., Poudel, B. R., \& Acharya, P. E. (2018). Social Enterprise and Social Entrepreneurship: Conceptual Clarity and Implication in Nepalese Context. NCC Journal, 3(1), 143-152. https://doi.org/10.3126/nccj.v3i1.20256

[26] Ramoglou, S., Stelios, •, \& Zyglidopoulos, C. (2014). The constructivist view of entrepreneurial opportunities: a critical analysis. Small Business Economics. https://doi.org/10.1007/s11187014-9590-4

[27] Ramoglou, S., \& Tsang, E. W. K. (2016). A REALIST PERSPECTIVE OF ENTREPRENEURSHIP: OPPORTUNITIES AS PROPENSITIES. Q Academy of Management Review, 41(3), 410-434. https://doi.org/10.5465/amr.2014.0281

[28] Schaltegger, S., Lüdeke-Freund, F., \& Hansen, E. G. (2016). Business Models for Sustainability: A Co-Evolutionary Analysis of Sustainable Entrepreneurship, Innovation, and Transformation. Organization \& Environment, 29(3), 264-289. https://doi.org/10.1177/1086026616633272

[29] Schwab, Klaus, \& Samans, R. (2016). Global Challenge Insight Report: The Future of Jobs. World Economic Forum, (January), 1-167. https://doi.org/10.1177/1946756712473437

[30] Schwab, Klaush. (2016). The Fourth Industrial Revolution. Retrieved from http://www.weforum.org 
[31] Shore, A. (2015). Student clubs: experiences in entrepreneurial learning Student Clubs: $\begin{array}{llll}\text { Experiences in Entrepreneurial } & \text { Learning. }\end{array}$ https://doi.org/10.1080/08985626.2015.1014865

[32] Short, J. C., Moss, T. W., \& Lumpkin, G. T. (2009). RESEARCH IN SOCIAL ENTREPRENEURSHIP: PAST CONTRIBUTIONS AND FUTURE OPPORTUNITIES. Strategic Entrepreneurship Journal Strat. Entrepreneurship J, 3, 161-194. https://doi.org/10.1002/sej.69

[33] Statistik, B. P. (2019). Keadaan Ketenagakerjaan Indonesia Agustus 2019. Retrieved from https://www.bps.go.id/pressrelease/2019/11/05/1565/agustus-2019--tingkat-pengangguranterbuka--tpt--sebesar-5-28-persen.html

[34] Subroto, W. T. (2015). Menanamkan Nilai-Nilai Entrepreneurship Melalui Pendidikan Ekonomi Pada Era Masyarakat Ekonomi Asean. Jurnal Economia, 11(1), 16. https://doi.org/10.21831/economia.v11i1.7751

[35] Syarizka, D. (2019). MSME'S Contribution to GDP 2019 Projected to Grow by 5\% Economics.Com. Retrieved January 9, 2020, from bisnis.com website: https://ekonomi.bisnis.com/read/20190109/12/876943/contribution-msme-to-gdp-2019projected-grow-5

[36] Technology, I. (2016). Table of Contents Assessing Foreign Language Learning Through Mobile Game- Based Learning Environments. 7(2). https://doi.org/10.4018/IJHCITP.2016040104

[37] Teece, D. J. (2010). Business Models, Business Strategy and Innovation. Long Range Planning, 43. https://doi.org/10.1016/j.lrp.2009.07.003

[38] Terzaroli, C. (2018). Developing entrepreneurship through design thinking: A new frontier for adult education. Epale Journal, (June), 20-27.

[39] Wirtz, B. W., Pistoia, A., Ullrich, S., \& Ottel, V. G. €. (2015). Business Models: Origin, Development and Future Research Perspectives. https://doi.org/10.1016/j.lrp.2015.04.001

[40] Wulansari, R., Rusnayati, H., Saepuzaman, D., Karim, S., \& Feranie, S. A. (2019). The influence of scientific creativity and critical worksheets (SCCW) on creative thinking skills and critical scientific as well as students' cognitive abilities on project-based learning work and energy concepts. Journal of Physics: Conference Series, 1280(5). https://doi.org/10.1088/17426596/1280/5/052039

[41] Yulastri, A., Hidayat, H., Islami, S., \& Edya, F. (2017). Developing an Entrepreneurship Module by Using Product-Based Learning Approach in Vocational Education. International Journal of Environmental and Science Education, 12(5), 1097-1109. 
[42] Zampetakis, L. A., Kafetsios, K., Lerakis, M., \& Moustakis, V. S. (2017). An Emotional Experience of Entrepreneurship: Self-Construal, Emotion Regulation, and Expressions to Anticipatory Emotions. Journal of Career Development, 44(2), 144-158. https://doi.org/10.1177/0894845316640898 